\title{
A Legal Framework of Foreign Banking in the Indonesian Banking System
}

\author{
Grace Henni Tampongangoy* Aminuddin Ilmar M. Arfin Hamid Nurfaidah Said \\ Faculty of Law, Hasanuddin University, South Sulawesi, Indonesia
}

\begin{abstract}
The legal work involved in systemic bank restructuring is an essential element of the government's microeconomic efforts. The existence of foreign banks in Indonesia is developing related to business and investment needs, where Indonesia is very need foreign capital but the presence of foreign banks in Indonesia from a legal perspective continues to experience problems, such as regarding the term of foreign banks. The research was conducted using a normative-legal research method. The research site was conducted at Bank Indonesia, the Office of the Financial Services Authority, the Office of the Deposit Insurance Corporation, the Indonesian Ministry of Foreign Affairs. The results show that the legal status of foreign banks in terms of two aspects, namely legal personality and legal capacity. Personality legal of foreign banks in Indonesia are branches or representatives of banks domiciled abroad, have license to operate in Indonesia according to applicable regulations in Indonesia, have rights, obligations and responsibilities that must be conducted according to the law in Indonesia. Legal capacity of foreign banks in Indonesia is a form of foreign bank legal entity following the form of its head office legal entity abroad. Supervision of foreign banks is conducted through coordination and cooperation between the host supervisory authority and home country as the main requirement for the effective supervision and operation of foreign banks and settlement of disputes can be made based on an agreement between the two parties to settle it with an international arbitration body, namely if the dispute resolution process is the court's authority in the country concerned.
\end{abstract}

Keywords: Bank; Foreign Banks; Investment; Legal Framework

DOI: $10.7176 / \mathrm{JLPG} / 85-23$

Publication date:May $31^{\text {st }} 2019$

\section{Introduction}

Indonesia is a legal State that aspired to realize people welfare. Clearly, the ideals of the welfare State are affirmed in the opening of the 1945 Constitution of the Republic of Indonesia and in order to realize this objective, Indonesia certainly needs huge funds as capital in the implementation of national development. An ideal situation is that capital needs can be fully met by the ability of capital in their own country. However, as it turns out into practice, in every developing country, the availability of capital for development as a whole is experiencing difficulties and to overcome it, one of the sources of funding for the state is through foreign investment. ${ }^{1}$

Foreign investment can provide benefits both directly and indirectly. Directly, foreign investment will provide additional funding for development and indirectly it can increase productivity and economic growth because through business processes, systems, management practices and new technologies, as well as a media link to export markets and supply chains internationally. Hence, the legal work involved in systemic bank restructuring is an essential element of the government's microeconomic efforts. It requires the application of international "best practices" for strengthening banking supervision and enforcement, incorporating international accounting and auditing standards, and rehabilitating or resolving insolvent institutions within the context of the overall legal and judicial structure. ${ }^{2}$

In Indonesia, the implementation of foreign investment is based on the provisions of legislation that has been established as a reference in its implementation so that it runs in accordance with national development goals. The legal basis for investment in Indonesia is contained in Act No. 25 of 2007 concerning investment (hereinafter abbreviated as Investment Laws). The spirit of the establishment of the Investment Law is the spirit to create a conducive investment climate. ${ }^{3}$ Therefore, this law regulates matters that are considered important, among others, the scope of laws, basic policies, and treatment of investment, as well as the relevance of economic development to the actors of the people economy. In addition, it also regulates the rights, obligations, and responsibilities of investors, investment facilities, authorization and licensing, coordination and implementation of investment policies which regulate institutions, investment matters and provisions regarding disputes resolution in

Ilmar, A. (2004). Hukum Penanaman Modal di Indonesia. Prenada Media: Jakarta. p. 102

Waxman, M. (1998). A legal framework for systemic bank restructuring. Available at SSRN 172984 or http://dx.doi.org/10.2139/ssrn. 172984

Purwanegara, M., Apriningsih, A., \& Andika, F. (2014). Snapshot on Indonesia regulation in mobile internet banking users attitudes. Procedia-Social and Behavioral Sciences, 115, 147-155. 
investment. ${ }^{1}$ This can be seen clearly in the general explanation of this law.

Foreign participation in banking in Indonesia is not only in the form of foreign ownership in Indonesian banks but it can also be through the establishment of a foreign bank in the status of a branch office or even a representative office with a head office in the country of origin. ${ }^{2}$ Until 2017, there were 40 banks owned by foreign banks in Indonesia. The description above shows that basically the presence of foreign in the banking system in Indonesia can be seen in 3 (three) forms, namely the establishment of a branch or representative office, the establishment of a new bank, and the purchase of shares in an existing bank.

The existence of foreign banks in Indonesia is developing related to business and investment needs, where Indonesia is very need foreign capital but the presence of foreign banks in Indonesia from a legal perspective continues to experience problems. There is no clarity regarding the term of foreign banks. The banking law does not use the term of foreign bank but uses the term of bank that is domiciled abroad but in documents issued by Bank Indonesia, the term of foreign bank is often used for foreign bank branch offices in Indonesia while private banks are incorporated under Indonesian law, although the majority of its shares are controlled by foreigners it is not considered a foreign bank. Banking regulations in Indonesia do not clearly regulate this matter, so that currently banks are Indonesian legal entities even though foreign majority ownership is still considered a non-foreign bank and subject to the Banking Laws while foreign bank branches or representatives are not regulated in the Banking Laws but in the Investment Laws.

These conditions arise the phenomenon of inequality between foreign banks and national banks due to unclear arrangements regarding the status, position and requirements of foreign banks in the banking system in Indonesia. Thus, the researchers were interested in conducting research to find a clear status and position of foreign banks in the banking system in Indonesia in terms of the position of foreign banks in the banking system and the position of foreign banks associated with investment law. The both aspects are expected to be able to create harmony between public and private interests in a foreign investment in the banking sector.

\section{Method of the Research}

The research was conducted using a normative-legal research method. It focuses on the study of the nature and legal status of foreign banking in Indonesia. Research on the legal status of foreign banks in Indonesia uses a philosophical approach, namely the disclosure of philosophical aspects underlying the legal existence of foreign banks in Indonesia by using 2 (two) perspectives namely legal capacity and legal personality. The location of research was conducted at Bank Indonesia, the Office of the Financial Services Authority, the Office of the Deposit Insurance Corporation, the Ministry of Foreign Affairs and the Directorate General of Law and International Agreements related to the existence of foreign banks.

\section{Status of Foreign Bank in terms of National and International Legal Relations}

The concept of legal status contains a mean as legal capacity as capacity to do something, capacity to act or briefly the capacity to possess rights and duties. The legal status that implies this legal capacity is closely related to the subject of law and legal personality, or in other words there is a close relationship between legal status consisting of 2 (two) forms, namely legal capacity with legal personality. ${ }^{3}$

In this context, legal personality is a characteristic for an institution to have rights and obligations in the law and submit claim legal personality can be seen in the statutes of the establishment of an institution that explicitly said its rights and obligations. However, often this is not explicitly stated so that it requires further search to determine its personal legality. Legal capacity is translated into Indonesian legal terms with "kepastian hukum." This term contains an understanding of what a person (human) can do in the framework of a legal system. This understanding implies that the law gives a certain "capacity" to every human being. The capacity provided by the law consists of "rights" and "responsibility" for the law. In general, the capacity given by the law is equal, which is reflected in adegium 'equality before the law'.

The hierarchical level of the sub-system includes an economic sub-system that functions as adaptation, a political sub-system that functions to achieve goals, a legal sub-system (social) that functions to integration, and a cultural sub-system that functions to maintain patterns. The legal status comes from the theory of Sibernetica as proposed by Talcott Persons was developed by legal expert Harrry C. Bredemeier with a legal function theory that views a law as an integrative mechanism. He built his analysis about the legal function as a mechanism of integration or integrator where the main functional observed in a social system, consisting of adaptation as an economic process, goal pursuance as a political process, pattern maintenance simply as a process socialization,

McLeod, R. H. (1992). Indonesia's new banking law. Bulletin of Indonesian Economic Studies, 28(3), 107-122.

Eko B. Supriyanto. Menyoal Kepemilikan Bank. Harian Kompas, Tuesday 21 June 2005. Accessed on 21 January 2018.

J. Pareira, M. (1986). Segi-segi Hukum Organisasi Internasional: Seri Organisasi Internasional (1A) Buku I: Suatu Modus Pengantar. cet. 1. Bandung: Binacipta. p.12.

4 Ibid. 
and integration as a legal process. ${ }^{1}$

The legal status is related to orderliness and order which is raised by the existence of the norms or provisions that govern them, among them are legal norms, so that social relations can take place in an orderly and orderly manner. ${ }^{2}$ Therefore, order is conditions for the ongoing relationship between fellow members of society in living life. The legal status is not only a tool used as an integration of power by the authorities. Likewise, political power is also needed to support the realization of legal functions. Understanding of this theory will be a reference to the status of foreign banks whether they have been able to realize the achievement of development objectives.

One sector governed by national and international law is the regulation of foreign banks. The existence of foreign banks in Indonesia is one of the realities of international civil law ${ }^{3}$ where the issue of international civil law related to foreign banks when viewed from: First, aspects of the business sector. The problem of International Civil Law of Foreign banks in terms of business aspects can arise when foreign banks have customers from various citizens who are subject to different laws.

Another problem is when an international trade transaction occurs where the parties involved originate from different countries with which laws are different which ones will be used in terms of business sector. The answer is the bank usually uses a certain standard form that includes the clause of the legal designation explicitly and usually applies the law of the country where the head office is located. However, if the bank does not use certain forms, the law will apply from the country where the branch office is located. The problem of collateral in the banking sector can lead to problems of International Civil Law but in this case the principle of Lex Rei Sitae applies which will determine which law applies. The principle of Lex Rei Sitae means that the law that applies to an object is the law of the place where the object is located or is in the form of tangible and intangible objects.

The second, in terms of employment aspect. The problem of International Civil Law will arise from aspects of labor, for example in a foreign bank there are Indonesian and foreign labor, law which will apply? the answer to the work agreement will apply law from the country where the work must be done. The principle of Lex Loci Solution, which means that applicable law is the place where the contents of the agreement are implemented, which will the basis of International Civil Law especially labor if a foreign bank whose place of operation in Indonesia employs workers from Indonesia and must apply the law of the country of origin of the foreign bank, then the agreement must be declared null and void by the judge. Because Indonesian law must be applied, in this matter law or regulation concerning labor law.

The third, in terms of capital aspect. The issue of International Civil Law will arise when the capital structure of a national bank is dominated by foreign banks. Several above matters indicate that the existence of foreign banks in Indonesia cannot be separated from the relationship between national and international laws, in this case International Civil Law. The principle of Locus Contractus, which means that an agreement that is an International Civil Law applies legal norms from the place of agreement or the place where the agreement is signed.

Thus, if there is a dispute between a national party and a foreign bank or a country with a foreign citizen, in this case national law is used, namely Indonesian law but does not reduce the possibility of this dispute can be under arbitration seen from its position, in the case of disputes that occur between foreign banks and Indonesian banks will apply the law of Bank Indonesia namely Commercial Law and International Law related to international agreements.

In an era of increasingly rapid globalization, the flow of movement experiences very rapid dynamics from one place to another supported by the flow of transportation and information. ${ }^{4}$ The speed of capital movements through investment is not only supported by easier and more global access to information, supported by reasons for investors to invest their capital and investment recipients to receive the investment. To this, various theories about investment, among others were put forward by Zaidun, ${ }^{5}$ who argued that in investment legal science the variant of thinking in understanding investment policies that could be chosen as basis for investment legal considerations/policies in terms of host country interests, namely Neo-Classical Economic Theory, Dependent Theory and the Middle Path Theory.

\section{Status of Foreign Banks in the Banking Legal System in Indonesia}

The economic development of a country cannot be separated from its involvement in the global economy. Various forms of cooperation are conducted in the form of direct- and indirect investments. This is done in various fields of economy and trade, including in the banking sector. The existence of foreign banks in Indonesia has gone through a long historical process. At the beginning of the New Order, the Ampera Cabinet Presidium instructed

Syaiful, M, (2010). Wajah Politik Hukum di Indonesia. Jakarta: Total Media. p.39.

Miru, A. (2011). Prinsip-prinsip perlindungan hukum bagi konsumen di Indonesia. RajaGrafindo Persada, pg. 31-32

Subagjo, F.O. (1977). Beberapa Masalah Hukum Perdata Internasional yang Timbul dari Bank Asing. p. 110

Irwansyah., Hakim. W., and Yunus, A. (2017).“Environmental Audit as Instrument for Environmental Protection and Management”. The Business and Management Review, 9(2), 228-232.

5 Zaidun. (2008). Kebijakan Hukum Investasi Indonesia. Bagian I. Suarabaya; Universitas Airlangga. 2008. p. 2. 
the Minister of Finance and the Governor of the Central Bank to give business licenses to several foreign banks to operate in Indonesia. In the instruction the number of foreign banks is limited based on the principle of reciprocity and the role of the country of origin of the foreign bank concerned as a source of foreign investment and/or a source of economic assistance. The reason for allowing foreign banks to operate in Indonesia at that time was for foreign banks to participate in facilitating the entry of foreign investment and the implementation of imports/ exports in Indonesia, developing domestic industries and production as well as expanding employment opportunities and increasing productivity for national potentials.

The government legal policy has clearly taken a stand to ensure that all government agencies, business people and entrepreneurs show a positive attitude towards the presence of foreign banks. In this positive attitude, it also includes the attitude to avoid and circumvent conflicting policies and regulations and not guarantee the certainty of work for foreign banks and violate common banking principles. Priori restrictions such as demand deposits, deposits and credit will narrow the activities of foreign banks so that they are inadequate compared to the risks they face in operating in Indonesia.

International trade is a trade relationship that develops rapidly and has a very broad scope even today is almost limitless because it has been done through trade relations using electronic information system technology. International trade relations that are cross-border in nature include many types and forms ranging from simple relationships to complex trade relations, those involving only 2 (two) parties to relationships involving many parties and many countries. The large and prosperity of countries in the world cannot be separated from the success and activities of these countries in international trade. Because, the glory of this country is inseparable from the policies of its government to conduct international trade. ${ }^{1}$

Banking institution is one of the legal subjects in international trade so that in international trade traffic, banking institutions are subject to the rules of international trade law. Banking institutions have strategic values in the economy of a country. The institution is intended as an intermediary for parties that have surplus of funds with those who need funds (lack of fund). Thus, banks will move in credit activities, and various services provided. Banks serve financing needs and launch a payment system mechanism for all sectors of the economy. In addition, banks also play an important role in the national development of a country. ${ }^{2}$

The bank also plays a very important role as a source of fund and financial intermediaries. Therefore, the regulation of banking is very closely related to the government's monetary policy. The flow of money from the collection of funds from the community in the form of deposits, demand deposits and then channeled again from the people in need in the form of credit. Therefore, the flow of money should be organized regularly and planned and directed towards the welfare of the community. The rapid growth of the national and international economy poses challenges to banking and financial institutions.

The strategic role of banking institutions that doing the main task as a vehicle for collecting and channeling funds effectively and efficiently requires continuous improvement in order to be able to have a comparative advantage. Banking institutions have a very large function and responsibility, in addition to having a traditional function, namely to collect and channel public funds in the sense of managing an abundant party of funds and providing credit or financing facilities for those who lack funds, in this case the bank performs financial intermediary functions, the bank also functions as a means of payment.

To achieve maximum benefit from banking activities, a banking system has been established that is used and applies in general and in its entirety, namely the nature and main functions of almost the same bank activities. Behind that, there are life links, and bank activities globally that cross cross-country boundaries, so it is not limited to a particular country but broadly encompasses the economic life of the world. ${ }^{3}$

The banking's role is very important for the development and progress of a country. In doing business activities, banks are not only looking for profit but are directed at improving community's living standards. This is a commitment for every bank that runs its business in Indonesia.

Referring to the provisions of the Banking Laws, the existence of foreign elements in bank ownership in Indonesia is basically consists of 2 (two) types, namely in the form of mixed and foreign banks where foreign banks are divided into 2 (two), namely branch offices and representative offices. The differences between the three types can be seen in the table below:

Adolf, H. (2014). Hukum Perdagangan Internasional, Jakarta: PT RajaGrafindo Persada. P. 39.

Djumhana, M. (1993). Hukum perbankan di Indonesia. Bandung: Citra Aditya Bakti. p.7.

Hadad, M., and Wimbo, S. (2004). Fungsi Intermediasi Bank Asing dalam Mendorong Pemulihan Sektor Riil di Indonesia. Jakarta: Fokusmedia. p. 11 
Table 1. The difference of Mixed and Foreign Banks

\begin{tabular}{clcc}
\hline No & \multicolumn{1}{c}{ Type } & Mixed Bank & Foreign Bank \\
\hline 1 & Ownership & Indonesian citizens and foreigners & Foreign \\
\hline 2 & Legal Entity & Indonesia & Follow home country \\
\hline 3 & Business Activities & Only certain fields & Only certain fields \\
\hline 4 & Establishment & Indonesian Law & Home country law \\
\hline
\end{tabular}

Source: Primary data, 2019 (edited).

The table above shows that there are clear differences between mixed banks and foreign banks, especially in the form of the legal entity and ownership of the bank. The equation of both can be found in the authority given in doing business activities. Both types of banks are given the authority to do activities for certain activities, namely:

a) International trade

b) Industry and production

c) Foreign/Mixed Investments

d) Loans that cannot be met by national private banks

Mixed- and foreign banks are given authority for certain activities as mentioned above, but they are also given the authority to conduct other business activities.

As described above indicates that foreign ownership in the banking system in Indonesia can occur through the establishment of a foreign branch company in Indonesia and can occur through the purchase of shares in commercial banks in Indonesia, but when talking about foreign bank ownership, only banks domiciled abroad have has a branch in Indonesia which is included in the category of foreign banks.

International provisions that are used as references by countries in banking arrangements, are issued by the Bank for International Settlements (BIS). The Bank for International Settlement (BIS) is actually a bank that is domiciled in Basel, Switzerland, formed by 11 industrial countries through the DenHaag Conference in January 1930. In practice this bank has functioned as an international organization functioning to promote cooperation between the central banks of the member countries and to provide international financial cooperation facilities. Today, with members who have reached around 120 central banks, the existence of BIS is becoming increasingly important. The rules issued by BIS became a reference for almost all the central banks in the world.

In Indonesia, the supervision mechanism in the form of inspection of foreign banks is regulated in Bank Indonesia regulation No. 2/6/PBI/2000. In relation to the supervision of foreign banks, coordination and cooperation between the host supervisory authority and the home country are the main requirements for effective supervision of the existence and operation of foreign banks. However, the reality of banking supervision in Indonesia has not provided a special regulation regarding supervision of foreign banks while it is undeniable that foreign banks have entities that are different from national commercial banks because the existence of foreign banks involves the bank's head office abroad so that the supervision of foreign banks must consider difficulties the difficulties that will be faced are related to relationships involving 2 (two) different legal systems.

All descriptions in the status of foreign banks in Indonesia indicate that foreign banks are domiciled abroad which have obtained license to do activities in Indonesia whose legal entity forms follow the form of the company's central legal entity, but in activities in Indonesia must be subject to regulations legislation in Indonesia and in the event of a dispute arises, the settlement is based on an agreement between the two parties unless the dispute that occurs is the authority of the court in Indonesia.

\section{Conclusion}

Legal status of foreign banks in terms of two aspects, namely legal personality and legal capacity. Legal personality of foreign banks in Indonesia are branches or representatives of banks domiciled abroad, have license to operate in Indonesia according to applicable regulations in Indonesia, have rights, obligations and responsibilities that must be conducted according to the law in Indonesia. Legal capacity of foreign banks in Indonesia is a form of foreign bank legal entity following the form of its head office legal entity abroad, supervision of foreign banks is conducted through coordination and cooperation between the host supervisory authority and home country as the main requirement for the effective supervision. However, operation of foreign banks and settlement of disputes can be made based on an agreement between the two parties to settle it with an international arbitration body after an agreement from the government of the sued country or under other conditions is prohibited to resolve through an international arbitration body, namely if the dispute resolution process is the court's authority in the country concerned. As a recommendation, it is necessary to synchronize and harmonize legislation that provides clear arrangements regarding position, legal status, form of legal entity, capital ownership structure, restrictions on business activities, rights and obligations, responsibilities of foreign banks with customers, and sanctions related to foreign banks in Indonesia.

\section{References}

Adolf, H. (2014). Hukum Perdagangan Internasional, Jakarta: PT RajaGrafindo Persada. 
Djumhana, M. (1993). Hukum perbankan di Indonesia. Bandung: Citra Aditya Bakti.

Eko B. Supriyanto. Menyoal Kepemilikan Bank. Harian Kompas, Tuesday 21 June 2005. Accessed on 21 January 2018.

Hadad, M., and Wimbo, S. (2004). Fungsi Intermediasi Bank Asing dalam Mendorong Pemulihan Sektor Riil di Indonesia. Jakarta: Fokusmedia.

Ilmar, A. (2004). Hukum Penanaman Modal di Indonesia. Prenada Media: Jakarta.

Irwansyah., Hakim. W., and Yunus, A. (2017)."Environmental Audit as Instrument for Environmental Protection and Management". The Business and Management Review, 9(2), 228-232

J. Pareira Mandalangi. (1986). Segi-segi Hukum Organisasi Internasional: Seri Organisasi Internasional (1A) Buku I: Suatu Modus Pengantar. cet. 1. Bandung: Binacipta.

McLeod, R. H. (1992). Indonesia's new banking law. Bulletin of Indonesian Economic Studies, 28(3), 107-122.

Miru, A. (2011). Prinsip-prinsip perlindungan hukum bagi konsumen di Indonesia. RajaGrafindo Persada.

Purwanegara, M., Apriningsih, A., \& Andika, F. (2014). Snapshot on Indonesia regulation in mobile internet banking users attitudes. Procedia-Social and Behavioral Sciences, 115, 147-155.

Syaiful, M, (2010). Wajah Politik Hukum di Indonesia. Jakarta: Total Media.

Waxman, M. (1998). A legal framework for systemic bank restructuring. Available at SSRN 172984 or http://dx.doi.org/10.2139/ssrn.172984

Zaidun. (2008). Kebijakan Hukum Investasi Indonesia. Bagian I. Suarabaya; Universitas Airlangga. 